\title{
$\infty$ 巻頭言 $\infty$
}

\section{超伝導と加速器 \\ 日本加速器学会会長 /高エネルギー加速器研究機構 生出 勝宣}

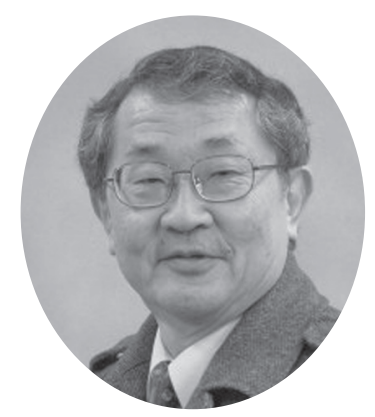

超伝導およびそのための低温工学が, 現代の様々 な粒子加速器において不可欠の技術である事は言を 待たないであろう。しかし，その不可欠さの度合いは 加速器の性質により異なる。例えば欧州原子核研究所 （CERN）で稼働中の Large Hadron Collider（LHC）で は最高 $7 \mathrm{TeV}$ の陽子ビームを曲げるために, 全周にわ たり最大 $8.4 \mathrm{~T}$ の超伝導電磁石を用いているが, これ を常伝導電磁石や永久磁石で置き換えることは, 周長 が $100 \mathrm{~km}$ 以上になるなど, ほぼ不可能と言ってよい。 LHC ほど大きな加速器でなくても, 強い磁場や磁場勾 配を必要とする場合には, 超伝導電磁石以外の選択肢 はない場合が多い。また, LHC などの超伝導電磁石で は電流を一定あるいはゆっくりと変化させるだけなの で, 低温部での発熱は殆どなく, 外部からの入熱だけ が冷凍機への負荷になり, 電力効率においても常伝導 電磁石に対して優位である。今後もより強磁場に耐え る高温超伝導線材の導入などにより, 超伝導電磁石は より広く加速器に利用されていくことは疑いない。

一方, 超伝導は高周波加速空洞としても加速器に用 いられる。しかし, この場合は超伝導電磁石のように, 常伝導に対する絶対的な優位性があるとは限らない。 そもそも高周波加速空洞はその中に蓄えた電磁場の工 ネルギーをビーム粒子に与え加速するものである。常 伝導空洞では空洞壁面での電気抵抗により電磁場の工 ネルギーは短時間に失われるので, ビームに伝わるエ ネルギーは投入した電力の $10 \%$ 程度である。これに 対して超伝導空洞では壁面のエネルギーロスは極めて 小さいので, 投入した高周波電力の $100 \%$ 近くをビー ムに伝えることができる。最大加速電界においても一 定の周波数以下の範囲では超伝導空洞の方が 2,3 倍 高いようである。

ところが，それでも超伝導加速空洞が常伝導空洞に 対して絶対的な優位にあるわけではない。その問題は, わずかであるとされた空洞壁面でのエネルギーロスで
ある。超伝導体といえども，Nbのような物質では交 流電磁場に対してはエネルギーの散逸を伴う。この工 ネルギーロスが冷凍機の熱負荷になるので, 電磁場か らビームへの伝達効率が良くても, 冷凍機を含めた全 電力効率は常伝導空洞のシステムに対して必ずしも優 位ではなくなってしまう。また，表面の交流口スは周 波数とともに増大するので, 常伝導空洞よりも利用可 能な周波数域が低い。ロスは電界強度の少なくとも 2 乗に比例するので, 加速勾配にも（空洞表面の臨界磁 場から決まる電界強度以下の）制約がつく。このよう な事情から, ある種の加速器では常伝導空洞が超伝導 空洞の方が同等あるいはそれ以上に適している場合も ある。現在一部で議論している国際リニアコライダー （ILC）は超伝導空洞を使うことにしているが，その選 択は決して直線的なものではなく，様々な議論を経た ものであった。

もし高温超伝導体で高周波加速空洞を作ることがで きれば，現状の超伝導が持つ上記の制約を一挙に打破 することは間違いない。それは今後の粒子加速器の姿 を一変させるであろう。例えば線形衝突型加速器では 衝突後の粒子のエネルギーを高周波電磁場として回 収・貯蔵し，また加速に用いることができる。こうす ればビームも低エネルギー部で周回させ, 直線部で加 速・衝突・減速を行う「エネルギー回収型コライダー」 が実現できる（現状でそれを行扔うとすると高周波貯 蔵時の冷凍機負荷が巨大になる)。もちろん，エネル ギー回収型線形加速器（ERL）なども大幅な電力の削 減が可能になるであろう。これまでのところ，まだそ のような高温超伝導空洞は存在しないが，個人的には 今世紀の加速器が開発すべき最大の課題であると思つ ている。

高温超伝導空洞の是非はともかく, 超伝導の重要性 は高まる一方ですので, 貴学会との連携協力を今後と もお願いする次第です。 